\title{
International Law: An Inventory
}

\author{
Edwin D. Dickinson* \\ T. INTRODUCTION
}

W SHaLl hear much of international law in the months and years
immediately ahead. Whether this is because the most devastating and disastrous of all world wars is at last over, or because the reorganization of the world under the United Nations Charter has at last been initiated, or because of a widespread conviction that we stand upon the threshold of an age of inescapable choice between international cooperation and obliteration, it is unnecessary for present purposes to inquire. Probably each is a contributing factor. In any case the period will be one of reviving interest in a system to which mankind periodically recurs when hope rises from the ashes of recent international disaster. The moment is preeminently one for inventory.

The need for inventory has been sharply indicated by the events which culminated in the signing of the United Nations Charter. The preliminary proposals, formulated in conferences of the four sponsoring governments at Dumbarton Oaks, were widely criticized, particularly among members of the legal profession, for their lack of emphasis upon international law and justice. Similar criticism was implicit in some of the amendments and proposals submitted later in behalf of other governments. In the result the Charter signed at San Francisco was drafted to include a number of provisions intended to repair the alleged deficiency.

The preamble of the Charter recites that the peoples of the United Nations are determined "to establish conditions under which justice and respect for the obligations arising from treaties and other sources of international law can be mamtamed." The statement of purposes in Article 1 includes the adjustment or settlement of disputes or situations by peaceful means "and in conformity with the principles of justice and international law." Article 13 provides that the General

A.B. 1909, Carleton College; A.M. 1911, Dartmouth College; Ph.D. 1918, Harvard University; J.D. 1919, University of Michigan. Emanuel S. Heller Professor of Law and Dean of the School of Jurisprudence, University of California. 
Assembly shall initiate studies and make recommendations for the purpose of "encouraging the progressive development of international law and its codification." International law is also the subject of significant reference in certaim articles of the Statute of the International Court of Justice. ${ }^{1}$

These references and the historic circumstances attending their incorporation in the Charter certainly invite a stock taking of our subject. Since international law is a subject of which relatively little is known among practicing lawyers, an attempt at stock taking would appear appropriate for the pages of a professional journal. What is international law? What does it embrace? How mature is it? How much reliance may be placed upon it as a means of adjustment in the perilous years ahead?

The occasion for inventory is happily provided by the timely appearance - within a few months of the end of war, of the signing of the United Nations Charter and of the dropping of the first atomic bomb-of a new and enlarged edition of the leading treatise by an American publicist. The first edition of Charles Cheney Hyde's International Lare, Chiefly as Interpreted and Applied by the United States, appeared in 1922 in two volumes. ${ }^{2}$ The second and revised edition, in three volumes, came froin the press as plans for the epoch marking Conference of San Francisco were nearing completion. ${ }^{3}$ It is here proposed to use the new edition of Hyde's treatise as the basis for an attempt at inventory. 4

Fortunately Hyde's conception of his subject is well adapted to this purpose. He is a realist. In his view the primary task of the in-

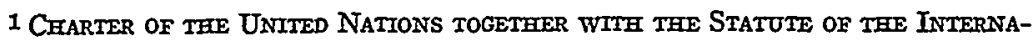
Tronat Court of Justice, Department of State, Publication 2353, Conference Series 74. See Statute, art. 2 (qualifications of judges); art. 36 (obligatory jurisdiction); art. 38 (governing law).

2 Reviewed by the present writer in 21 Mrcr. L. Rev. 237.

3 HYDE, INTERNATTONAL LAW (1945).

4 Hyde's treatise will be cited throughout by volume and page. There will be occasional reference to 1 OpPENHETM, INTERNATIONAL LAW (Lauterpacht's 5th ed., 1937) and 2 OpPENHEns, INTERNATIONAL LAW (Lauterpacht's 6th ed., 1940). Publications of the Research in International Law (1929-1939) will be cited for the material to be found in the comment rather than for the suggestions incorporated in draft conventions. There will also be occasional reference to special collections, studies or articles thought to be especially illuminating in connection with the project lere undertaken. There has been singularly little of critical appraisal in modern writing on international law. BRIERLY, THE OUTIOOK FOR INTERNATTONAT LAW (1944) is a notable exception and in all respects the most penetrating and profound of recent contributions. 
vestigator is "to see things as they are, and if he attempts to mirror the law, to let no play of imagination or vision of the future mar the accuracy of the portrayal." $\mathrm{He}$ defines international law as "the principles and rules of conduct declaratory thereof which States feel themselves bound to observe, and, therefore, do commonly observe in their relations with each other." Its basis has been the acquiescence of independent states, ${ }^{7}$ its sources custom and treaties, ${ }^{8}$ and its ultimate sanction the power of those who support it. ${ }^{9}$ As in his original edition, Hyde seeks particularly "to mirror the views of his own country." Following the general plan of his treatise, we may begin appropriately with the subjects or persons of international law.

\section{PERSONS OF INTERNATIONAI LAW}

The persons of international law are states. States in the international sense are bodies politic of substantial population, occupying fixed territory, under competent government, and having capacity to enter into relationships with the outside world. ${ }^{11}$ Tested by these criteria, the community of international law is found to consist of independent and dependent states, the former being "equal in the sense that they resemble each other in possessing and enjoying the same privilege of freedoin from external control in the management of their domestic or foreign affairs," subordinated to other states. ${ }^{13}$ It is apparent that dependence defies precise classification and is best portrayed with reference to its various historical manifestations.

Accordingly Hyde proceeds to review at length various historical examples of dependency, including suzerainties, protectorates, neutralized states, mandates, unions of states, and the like. ${ }^{14}$ Particular attention is devoted to the relationships which have been established

$5 \mathrm{I}, \mathrm{ix}$.

$6 \mathbf{I}, 1$.

$7 \mathrm{I}, 4$.

$8 \mathrm{I}, 10$.

$9 \mathrm{I}, 19$.

$10 \mathrm{I}$, vii. Hyde served as Solicitor for the Department of State of the United States, 1923-25. Views of the United States are amply docuniented in MOORE, DIOESX OF INTERNATTONAL LAW (1906) and HackWORTH, Digest OF INTERNATTONAL LAW (1940-1944).

11 I, 22. Cf. 1 OPPENHETar, op. cit. supra note 4, 112-113.

$12 \mathrm{I}, 27$.

13 I, 44. Cf. 1 OPPENBETM, op. cit. supra note 4, 111-118.

14I, 44-129. Cf. 1 OPPENBEIM, op. cit. supra note 4, 155-216. 
over more or less protracted periods between the United States and Cuba, Panama, the Dominican Republic, Haiti and Nicaragua: ${ }^{15}$ The recent amelioration of these relationships is presented as matter of national policy, ${ }^{16}$ since "it inay be doubted whether international law endows a State not in fact independent with any privilege of attaining independence. .117

The presentation of this initial phase of the subject leaves it implicitly clear that international law, so far as its subjects are concerned, has achieved no more than the acceptance and attempted rationalization of the world as it is. It begins of necessity with the world's peoples, their appurtenant geographies and governments, their cultures and common or conflicting interests, and endeavors to make a minimum of juristic sense of the chaos thus presented. About the individual subject it throws no regime of protection or security comparable to the regime established for the benefit of the individual in the more mature systems of national law. We may thus look for nothing comparable to the progress from status to contract and from contract to relationship which has done so inuch within reasonably well governed nations to provide opportunity and security for the individual. Against this somewhat melancholy background, it may well be that the grandiloquent phrases of the preamble of the United Nations Charter liave a more significant purpose than has been commonly appreciated. In any event freedoin from external control is the common characteristic of independent states and, it may be added, the common aspiration of peoples in a dependent condition. ${ }^{18}$

\section{BIRTH, LIFE AND FREEDOM}

The birth of the state, according to Hyde, "may be attributable to the revolution of a colony, or to the secession of the inhabitants occupying a portion of the territory of a State, or to the determination of a controlling group of powers to establish and recognize a new State within territory previously belonging to an existing State."19 There is no right to be born nor is there any right to be born independent.

\footnotetext{
$15 \mathrm{I}, 56-84$.

10I, 83-84.

17 I, 43.

${ }^{18}$ Cf. UnITEd Nations Cerarter, op. cit. supra note 1, art. 73, par. b; art. 76, par. b.

$10 \mathrm{I}, 147$.
} 
State birth, moreover, is neither an assurance of normal state life nor of the privileges of normal intercourse with other states. The assurance comes only through recognition by other states. ${ }^{20}$ Such recognition may be joint or several, formal or informal, express or implicit. As a matter of good neighborhood the timing is generally important. Even after recogintion has given assurance to statehood, normal intercourse may be frustrated or suspended by the withholding of recognition from a new government. The granting, withholding or withdrawing of recognition, whether in relation to a new state or the new government of an existimg state, is matter of policy. There is no duty to recognize. And policy, as the experience of the United States has demonstrated, may fluctuate within elastic limits. ${ }^{21}$

As there is no right to be born and no right to be recognized, so there is no right to continued existence. The welfare of the international society "may not require the maintenance of a particular State; its very extinction may be deemed to be for the general good."22

So long as the state enjoys an independent existence, however, international law concedes it a freedom from external control which is significantly extensive. The incidents of its legal status include the right to acquire and hold territory, to adopt whatever form of government it chooses, to enact such laws as it may see fit, to determine the allegiance of its nationals and generally to treat them as it may see fit, to control the admission of aliens into its territory, to expel objectionable aliens or classes of aliens, to determine freely the kind and amount of intercourse it will have with other countries, to resort to force in self-defense, and to exclude the unwarranted intervention of others in its domestic or foreign affairs. ${ }^{23}$ Within the widest of limitations it is free to live its own life in its own way.

In his treatment of the juridical incidents of this freedom, Hyde is constramed to place a consistent emphasis upon rights. The correlative obligations which might be expected to bulk large in a more mature legal system are generally found to be ill-defined, precariously established or matter of aspiration. Thus the choice of constitution or government is of no concern to the international society "unless the form of government adopted be of a kind notoriously

\footnotetext{
20 I, 148. Cf. 1 OPPENHETM, op. cit. supra note 4, 118-142.

22 I, 161-182. As to the possible effect of provisions of the United Nations Charter concerning membership, particularly arts. $4-6$, query?

22 I, 204.
} 
opposed to the existing order of affairs in that society, and calculated, therefore, to render the State impotent to perform its common obligations as a member thereof."24 The exercise of freedom to legislate should not "expose the State to the charge of unfaithfulness to an international obligation.".25

While the state may do as it will with its own nationals, its treatment of them inay be so "contemptuous of the dictates of humanity" as to "shock the sensibilities of foreign states" and induce them to "voice their regret or indignation." "It is to be expected," says Hyde, "that the international society will ultimately evince an interest in the welfare of the private individual sufficient to cause the law of nations to restrict the freedom of a State in its treatment of its nationals." Certain provisions of the peace treaties concluded at the end of the first world war may have been "prophetic of what the future has in store." ${ }^{26}$ Hyde would no doubt agree that important provisions of the United Nations Charter are in line with earlier prophecy. ${ }^{27}$

The expulsion of aliens is clear matter of right, but must not be arbitrary or in bad faith. ${ }^{2 s}$ Discriminations in the exclusion or admission of aliens are clearly permissible, but those aimed at particular areas or races are described as "tokens of arrogance that defy explanation and produce resentment on the part of States whose nationals happen to be singled out for exclusion."

Freedom of intercourse, we are told, may not be carried to the extreme of complete isolation. ${ }^{30}$ Acts of self-preservation must be "strictly acts of self-defense." Intervention is narrowly defined to include "the interference by a State in the domestic or foreign affairs of another in opposition to its will and serving by design or implication to impair its political independence." Such action "may or may not be lawful," depending upon the relation between its scope and the gravity of the misconduct which is alleged in justification. ${ }^{32}$ Prac-

\footnotetext{
23 I, 205-281. Cf. 1 OPPENHETA, op. cit. supra note 4, 217-270.

24 I, 207-208. Cf. BRIERLY, op. cit. supra note 4, 109.

$25 \mathrm{I}, 208-209$.

$26 \mathrm{I}, 209-212$.

27 Note particularly art. $1, \S 2$; art. $13, \S 1$, par. b; art. 55 , par. c; art. $62, \S 2$; art. 76 , par. c. And cf. BRIERLX, op. cit. supra note 4, 108-117.

$28 \mathrm{I}, 230-236$.

$29 \mathrm{I}, 216-218$.

$30 \mathrm{I}, 212-213$.

31 I, 237-238. Cf. United Nations Charter, op. cit. supra note 1 , art. 51.

$32 I, 245-247$.
} 
tice of late has been more creditable in this respect among the American republics than elsewhere. Considerable space is given at this point to discussion of the Monroe Doctrine. ${ }^{33}$

As in the initial phase of our subject, the international law of state life and freedom is characteristically the juridical rationalization of a chaotic status quo. Expediency and policy hold extensive areas against the encroachments of right and duty. There is a persistent emphasis upon right and an equally persistent uncertainty as to the scope of correlative obligation. Too often the obligation to be decent is discernible only in the formulae of juridical aspiration. Wherever asserted rights are in conflict the play of self-help has an embracing significance. In brief, and notwithstanding its great age, we are reminded that international law is a system of impressive immaturity. ${ }^{34}$ While the affirmations of its purpose no doubt provide a check on violence, it is a frail and imperfect antidote for complete disorder.

\section{PROPERTY AND CONTROL}

From law concerned primarily with the state as an international person we pass to law concerned with the state's interests of property and control. Here, if only because of the nature of the subject matter, we may expect to find somewhat more of juridical substance and coherence. And we do, not only because of the nature of the subject matter, but also because custom has been considerably fortified with borrowings from the Roman Civil Law and extensively supplemented through development of the law in treaties.

Dominion over territory, we learn, may rest upon discovery and occupation, accretion, or subjugation, and may be transferred by cession, relinquishment, prescription, revolution or annexation. ${ }^{35}$ of these, the law of discovery and occupation approached maturity in the mineteenth century only to lose most of its practical importance. It is inapplicable in the polar regions, with respect to which other practices are now in the making. ${ }^{36}$ The law of accretion is well settled and relatively unimportant. ${ }^{37}$ Subjugation disassociated from

33 I, 281-317.

34 Cf. Brterdy, op. cit. supra note 4, 1-18 and passim. Also Brierly, The Shortcomings of International Law (1924) B.Y.B. INT. L. 4-16.

35 Cf. 1 OpPENEEIM, op. cit. supra note 4, 349-460.

36 I, 347-355.

37 I, 355-356. 
formal cession has become chiefly of historical interest. ${ }^{38}$ Transfer by formal cession, whether coerced or freely negotiated, is generally solemnized im formal treaty and as a matter of policy appears to be increasingly affected by concern for the ethnographic and other equities of the inhabitants. ${ }^{39}$ Transfer by relinquishment is infrequent and relatively unimportant. ${ }^{40}$ The possibility of transfer by prescription is recognized, though there is no agreement as to the prescriptive period; the requirements of possession are left dependent upon the circumstances of each case; and opportunities for invoking the principle are thought to be on the decline. ${ }^{41}$ Transfer by revolution is perfected by the revolution's success. ${ }^{42}$ Transfer by annexation may "reveal the fruition of subjugation, or the achievement of a powerful State which although avoiding recourse to war overrides the will of another and by eliminating substantial opposition seeks to enlarge its own domain, or the complete harmony of purpose between the States concerned." 43

Where territory is transferred from one state to another, the extent to which the transferee is burdened with the obligations of its predecessor is found to be a subject of "discord rather than harmony of view." ${ }^{24}$ Legislative and political power go with the transfer, ${ }^{45}$ of course, but laws in force continue operative until changed by the transferee. ${ }^{40}$ A more "illusive task" is the determination of effect upon public debts. Where a state succeeds to part only of the territory of another state, purely local debts should go with the territory..$^{47}$ As regards general debts, Hyde argues effectively for the principle of equitable apportionment in the light of "benefits accruing to the territory transferred." ${ }^{48} \mathrm{He}$ concludes that "there is need of general

$38 \mathrm{I}$, 356-358.

39 I, 358-378. Elsewhere Hyde says: "It is probable that before the close of the present century the validity of changes of sovereignty over territory will be regarded as dependent in large degree upon the consent of the inhabitants of the areas concerned." I, 414. Cf. United Nations Cerarter, op. cit. supra note 1, art. 1, \$2; art. 55; art. 73; art. 76.

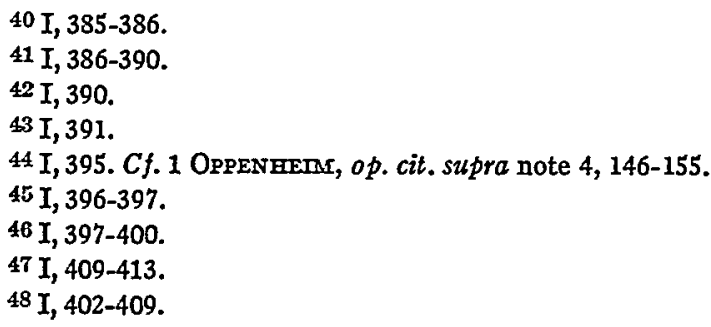


agreement respecting the application of this fundamental test." ${ }^{\prime 40}$ Where a state succeeds to the entire territory of another state, there should be general succession to fiscal obligations. The obligation is not unlimited, however, and practice is far from uniform. ${ }^{50}$ Contracts and concessions of local benefit should likewise be respected by the transferee and there is considerable practice to that effect, though pending the evolution of a firmer practice it is desirable that the treaty of cession specify the course to be pursued. ${ }^{51}$ The transferee's obligation to respect private rights has been repeatedly affirmed and is supported by a substantial body of decision and practice. ${ }^{62}$

The limits or boundaries of the state's domain are established at artificial or natural frontiers. With improvements in the techniques of cartograplyy, artificial boundaries present fewer difficulties than formerly. The watersleed line of boundary hills or mountains is simple in principle and frequently difficult in application. River boundaries generally follow the thalweg in navigable streams and the median line in others. Frontiers in the marginal sea are another matter. Here there is sharp division between those states which, like the United States, have contended vigorously for a three-mile belt of territorial waters and other states which have contended with equal vigor for a wider zone. There is even lack of agreement concerning the manner of drawing a line between territorial waters and the high seas. The most that can be said on this important subject is that states are generally agreed that territorial waters should extend seaward for at least three nautical miles. The Hague Conference for the Codification of International Law of 1930 could only report difference of opinion as to the width of the zone and no attempt was made to submit a convention. ${ }^{53}$ As regards territorial bays there is even less of agreement. Common use of the term "historic bays" is șignificant. "The individual State," says Hyde, "has in practice enjoyed much latitude in determining what bays or arms of the sea penetrating its territory may be regarded as a part of the national domain and dealt with accordingly." ".54 There is no present consensus and the Hague

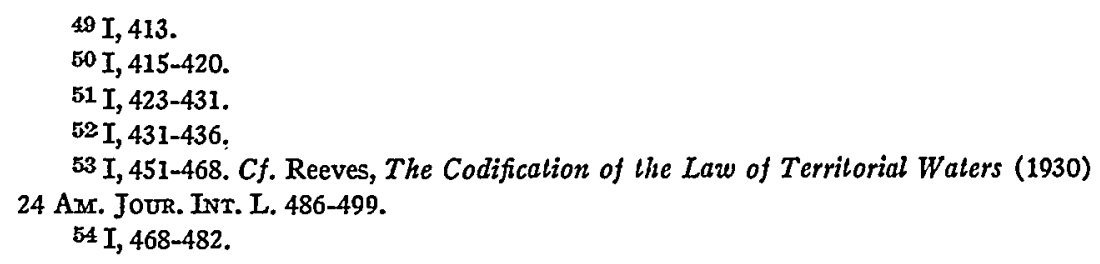


Conference was able to establish none. Similarly there are "historic straits" rather than bases of general agreement. ${ }^{5 \overline{5}}$ Possibly it is misdirected effort to seek agreement on principles of universal application in these matters in view of the varied physiographic conditions with which a fickle nature has endowed nnembers of the family of nations.

Within its domain the state's control is not unlimited, though limitations sanctioned by general law are narrow in scope and are commonly attributable to geographic considerations. General privileges, such as innocent passage through marginal seas, are founded upon custom. ${ }^{56}$ Special treaty privileges, such as leases, fishing rights, rights of passage, or rights of non-fortification, are sometimes described as servitudes; but the applicability of analyses borrowed from private law is debatable. 57 There is as yet no generally acknowledged duty to yield privileges of transit by land; but there is a considerable body of conventional arrangement. ${ }^{58}$ The regimes of straits, ${ }^{59}$ international waterways ${ }^{60}$ and international rivers ${ }^{61}$ are frequently established by treaties in the light of geographic, commercial or political considerations and in response to particular requirements of the contracting parties. For rivers particularly there has been developed an extensive body of what Hyde calls "fluvial conventional law."122 There is uniformity only where the fundamental problems are substantially similar. The ultimate decision is assumed to rest with the riparian proprietors and such regines "attain their greatest usefulness when confined to the solution of the problems of navigation and commercial intercourse that are peculiar to particular river systems sought to be dealt with." ${ }^{13}$ Whether international law sets any limits on the diversion of waters from an international stream is a mooted question; there is nothing comparable to the law developed in domestic adjudications between states of the United States; and the subject is one most appropriate for adjustment through negotia-

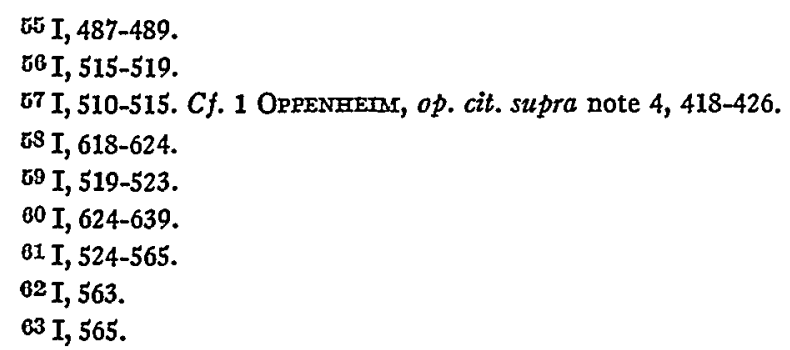


tion and treaty. ${ }^{64}$ There is a privilege of access to ports for foreign vessels of commerce; but the territorial sovereign possesses "the broadest right" to determine which ports shall be open to commerce and to regulate access thereto. ${ }^{6 \overline{5}}$

In addition to land and waters and an extension into the adjacent seas, the state's domain includes the air space over its territories. Hyde anticipates that community of interest will stimulate an increasing development of conventional regulation. Numerous bipartite and multipartite treaties have already been concluded and the development is still in its infancy. He suggests that it is too early to forecast whether the tendency will be toward liberalization of privileges of flight or toward maintenance of rigid national controls. ${ }^{60} \mathrm{It}$ is noted that communication by radio has already become the subject of an extensive body of general conventional regulations whereby states accept important restrictions in the common interest. ${ }^{67}$

Within its domain of land, water and air the state's control is prima facie supreme and exclusive. The civil, administrative or military authorities of other states may encroach only with the express or implied consent of the territorial sovereign. Exceptions are noted only where the safety of foreigners in their persons or property is jeopardized by the indisposition or impotence of the territorial sovereign to afford adequate protection. "The price of the inviolability of any territory," says Hyde, "is the maintenance of justice therein." 68 In general the state has final authority within its bounds with respect to civil and political rights, ownership and control of property, pursuits and occupations, creation and functioning of corporations, taxation of persons and property, imports and exports, protection of industrial and literary property, concessions and monopolies, trade and exchange, police and quarantime regulations, and the like. ${ }^{00}$ International law presents few obstacles to discrimination against aliens; but it is noteworthy that modern commercial treaties tend to alleviate inequalities of privilege, that the hardships of multiple taxation

64 I, 565-577.

$65 \mathrm{I}, 581-585$.

66 I, 585-605. Cf. Final Act and Appendixes of the International Civil Aviation Conference of 1944 (1945) 39 AMr. Jour. INT. L. Supp. 111-143.

Bi I, 605-617.

$68 \mathrm{I}$, 646-649.

69 I, 649-702. 
are increasingly mitigated by special agreements, ${ }^{\text {T0 }}$ and that the protection of industrial and literary property has long been implemented through multipartite conventions and international administrative unions. ${ }^{71}$ Freedom of religion and freedom of speech and the press are matters determined by the policy of each state. ${ }^{\mathbf{7 2}}$ The immovable property of aliens is said to be secured against expropriation without just compensation, $m$ conformity with the view vigorously defended by the United States, thus barring expropriation where the state is unable to compensate; ${ }^{73}$ but it may be doubted whether so extreme a view has ever been generally accepted and the current is probably running against it. ${ }^{74}$ Supremacy should beget a measure of responsibility and perhaps does with respect to such obvious and tangible things as terrorist activities or the release of destructive fumes. ${ }^{\text {T5 }}$ Recognition of duty has been sporadic, however, and it can only be said that the practices of states fail to reveal a significant deference for the principle of correlative obligation.

It thus appears that international law fares somewhat better with respect to property and control than with respect to topics previously examined. The subject matter is somewhat less elusive. The community of interest is generally more apparent. The urgency of order has pressed a little more firmly against considerations of national policy. Rationalization has been extensively fortified by recourse to private law sources and analogies. ${ }^{76}$ Bipartite and multipartite treaties of rule-making effect have spread a network of useful principle and procedure in areas previously notable for the deficiencies of custom.

These virtues are impressive, however, only upon comparison with other and more chaotic phases of the same system. More rigorous comparisons, particularly with the legal systems of better orgamized societies, suggest that the international law of property and control is essentially a thing of shreds and patches. Especially notable are deficiencies of derivation from a chaos of conflicting practices, de-

$70 I, 663-676$.

71 I, 680-687.

72 I, 702-710. Cf. UNITEd NATTONS CHARTER, op. cit. supra note 1, art. 1, $\$ 3$; art. 13, par. b; art. 55, par. c; art. 76, par. c.

73 I, 710-722.

${ }^{4} \mathrm{Cf}$. Williams, International Low and the Property of Aliens (1928) B. Y.B.L. $1-30$.

75 $1,722-725$.

76 Cf. Lauterpacet, Prtvate Law Sources and Analogies of International Law (1927) $91-133$ and passim. 
ficiencies of adaptability fostered by efforts to impose universal precepts on geographic or cultural conditions of the widest variation, ${ }^{77}$ deficiencies of development stemming from an utter inadequacy of procedures for keeping abreast of changing conditions, deficiencies of balance manifested, as previously noted, in a persistent emphasis upon right and an equally persistent uncertainty as to correlative obligation, and deficiencies of remedial device disclosed in repeated and unavoidable reference to the import of self-help. These are no hall-marks of excellence. They are the indicia of a primitive and extremely imperfect system.

\section{JURISDICTION}

From consideration of the state's interests of property and control it is an easy step to the consideration of its jurisdiction. Within its territorial domain the state is primarily and well-nigh exclusively responsible for the determination of what shall be lawful or unlawful and of the effects to be attributed accordingly. This responsibility it discharges through the legislative, executive and judicial arms of its government. Theoretically, there can be little overlapping between states and correspondingly few limitations. As Hyde says, "save for the general obligation to conform to the practices of civilization, a State is unfettered in its choice of forms of procedure or in the adoption of a particular code."is The courts of one state will not sit in judgment upon the acts of government of another within its own territory. ${ }^{79}$ And the absence of any international rule requiring mutual judicial assistance is noted chiefly as accentuating "the need for conventional arrangements. $\$ 180$

Actually there is a good deal of overlapping and corresponding limitations have been found necessary. No state may subject another to its jurisdiction without the latter's consent. ${ }^{81}$ The officials which states employ in conducting international intercourse have long enjoyed extensive jurisdictional immunities. In the case of diplomatic personnel, these immunities are founded on ancient custom, fortified and defined in a substantial body of national laws and decisions ${ }^{82}$

i7 Cf. BRIERLY, op. cit. supra note 4, 39-41.

78 I, 729.

79 I, 734.

$80 \mathrm{I}, 732$. Cf. Research in International Law, Judicial Assistance (1939) 33 AMr. Jour. INT. L. SUPP. 11-166. 
and, except as to the immunities which may be claimed for unofficial staff, are the subject of a substantially uniform practice. ${ }^{83}$ Consular officials are not diplomatic officers and cannot claim the same immunities as of right. Under modern consular conventions, however, they are accorded a wide variety of privileges and immunities considered essential to their successful functioning. ${ }^{84}$ With even stronger reason the visiting head of a foreign state is accorded local exenption for himself and his entourage..$^{55}$ So also as to a foreign military force entering the state with its consent or, if the expedition is internationally excusable or justified, without its consent. ${ }^{86}$ So also as to a foreign vessel of war or a ship devoted to foreign public service. ${ }^{87}$ The increasing nationalization of merchant vessels and their eniployment in commercial enterprise under government control have raised more difficult questions with respect to which practice is divergent or unsettled. ${ }^{8 s}$ Comparable problems are in the making with respect to foreign state aircraft; ${ }^{89}$ and uncertainties arising from the increasing tendencies of states to acquire property abroad call urgently for general agreement if international law is to "remain flexibly responsive to the requirements of international intercourse."

Overlapping and corresponding problems of adjustment are the rule rather than the exception in important areas of maritime jurisdiction. In general "vessels on the high seas are subject to no authority except that of the State whose flag they fly." When merchant vessels flying the flag of one state put into the ports of another, it might be assumed that they would pass wholly under the jurisdiction

\footnotetext{
81 Cf. Research in International Law, Competence of Courts in Regard to Foreign States (1932) 26 AMr. Jour. INT. L. SuPP. 451-738.

82 Cf. Feller and Hudson, Diplomatic and Consular Laws and Regulations (1933).

83 II, 1263-1290. Cf. Research in International Law, Diplomatic Privileges and Immunities (1932) 26 Axr. JouR. INT. L. SUPP. 15-187.

84 II, 1322-1367. Cf. Research in International Law, Legal Position and Functions of Consuls (1932) 26 Axr. Jour. INT. L. SUPP. 189-449; FerLer ANd Hudson, op. cit. supra note 82 .

$85 \mathrm{I}, 817-819$.

86 I, 819-822.

$87 \mathrm{II}, 823-838$.

88 II, 838-840. Cf. 1 Oppentem, op. cit. supra note 4, 668-670.

$89 \mathrm{II}, 840-841$. II, 1271.

$90 \mathrm{II}, 841-849$. $C f$. the ancient rule as to inviolability of diplomatic premises,

$81 \mathrm{I}, 751$.
} 
of the latter and there is much theoretical assertion to that effect. Practically, however, it has been found convenient to recognize limitations on the jurisdiction of the territorial sovereign with respect to internal matters affecting the ship and its occupants only. ${ }^{92}$ Whether these limitations rest upon comity, or upon a binding custom, or upon the provisions of treaties is disputed. ${ }^{03}$ Whatever the approved theory, the practice is general. If the foreign ship is forced into port in distress it is conceded an even larger measure of exemption under customary law..$^{04}$ Likewise if it is passing through the maritime belt in innocent passage..$^{95}$ It is with respect to the high seas outside the maritime belt, and particularly with respect to the adjacent seas where problems of protective jurisdiction are acute, that practice has been more unsettled and writers less successful in their endeavors to rationalize the authority which states actually assert. The foreign ship which offends within territorial waters and flees to the high seas may be taken thereon in "hot pursuit" commenced in territorial waters.08 Presumably the foreign ship which offends within territorial waters from a position immediately outside or adjacent thereto may be taken on the high seas, as a protective measure, if the flag state is unable or unwilling to prevent or abate the wrong. Over foreign vessels inbound most maritime states exercise a more or less extensive protective jurisdiction outside the maritime frontier in the enforcement of revenue, sanitary, sumptuary, police or security laws. ${ }^{97}$ While the validity of the general principle must undoubtedly be admitted, the scope of its permissible application is anything but clear and important maritime states are prone to assert against others assumed limitations which their own conduct has belied. As regards hovering ships under foreign flag there is confusion of practice and even less of clarifying rationalization. ${ }^{98}$ On the high seas as such, and aside from the jurisdiction over national ships and the protective jurisdiction noted above, there

92 I, 735-743.

93 Cf. Charteris, The Legal Position of Merchantmen in Foreign Ports and National Waters (1920-21) B.Y. B.INr. L. 45-96.

$94 \mathrm{I}, 743-745$.

$95 I, 749-751$.

06 I, 794-797.

97 Cf. the present writer's Jurisdiction at the Maritime Frontier (1926) 40 Hanv. L. REv. 1-29.

${ }^{98} \mathrm{I}, 777-794$. On the general subject, cf. Research in International Law, Law of Territorial Waters (1929) 23 AMr. JOUR. INT. L. SUpp. 241-399; JEssup, THE LAW OF Territoriat Waters aNd Maritine JuRISDiction (1927) 75-112 and passim. 
is firm customary authority only with respect to pirates ${ }^{99}$ and a closely restricted treaty authority in conventions for the suppression of the slave trade, the traffic in arms, or pelagic sealing..$^{100}$

In or under the high seas there are vast riches of inarine life and mineral resource of immeasurable benefit to mankind if properly conserved. Jurisdiction to conserve, however, has been largely frustrated by negation. Suggestively entitled "the exploitation of the riches of the sea," the subject is said to require measures of cooperation which hitherto have been largely lacking. Apart from the "special equities" which certain states have successfully asserted in the banks or sedentary fisheries near their coasts and the special regimes which have been set up by treaty among states willing to cooperate in the regulation of pelagic sealing, whaling or certain types of deep sea fishing, the conservation of sedentary, deep sea or anadromous marine life has remained largely a matter of hope. ${ }^{101}$ Sinilar frustrations threaten to impede the development of mineral and other marine resources. In brief, a little useful practice, a modicum of conventional agreement and a conspicuous uncertainty of policy in important quarters totals something akin to juridical insolvency with respect to interests of increasing concern to the family of nations. ${ }^{102}$

As regards the jurisdiction of crime, varied national practices and an increasing facility of transport and cominunication have compelled somewhat ampler bases of understanding and a more effective cooperation through formal agreements. It is universally recognized that states are competent to define and punish crimes committed within their territories; and the territorial principle has been greatly expanded in modern times through national legislation expanding the definition of particular offenses or expanding the jurisdiction of territorial offenses generally. Equally extensive is the jurisdiction of the state with respect to crimes on its public or private ships, and probably with respect to crimes committed on its aircraft, wherever they may be. Outside the national domain or places assinilated thereto, a state has jurisdiction with respect to any crime committed anywhere by one of its nationals and probably, to a limited extent at least, by

${ }^{09}$ I, 767-777. Cf. Research in International Law, Piracy (1932) 26 Am. Jour. INT. L. Supr. 739-885; Morrison, A Collection of Piracy Laws of Various Countries, 26 ibid., 887-1013; and the present writer's Is the Crime of Piracy Obsolete? (1925) 38 Harv. L. REv. 334-360.

$100 \mathrm{I}, 764-767$.

101 I, 753-763. Cf. 1 OppeNHetn, op. cit. supra note 4, 493-497. 
persons assimilated to nationals. Most states assert a more or less comprehensive jurisdiction with respect to crimes committed by aliens outside the territory against the safety of the state. A considerable number of states also assert jurisdiction of crimes against nationals as well as a jurisdiction that is universal in theory but generally circumscribed by practical safeguards. In the result there is, potentially at least, a vast deal of overlapping and corresponding need for the reconciliation of conflicts. ${ }^{103}$

The increasing facility of transport and communication has long since compelled a substantial measure of cooperation through mutual rendition of fugitives from criminal justice. There is no obligation to extradite apart from treaty; but actually, during the past one hundred and fifty years, the world has come to be increasingly encompassed by a network of extradition agreements. The scope of these agreements has been progressively expanded, moreover, and the procedures improved. There are indications, indeed, that groups of states have now reached the point at which it may be considered practicable to supersede a multiplicity of bipartite treaties with multipartite treaties of general rule-making effect. Notwithstanding the difficulties which have been encountered with respect to the rendition of nationals, the definition of non-extraditable political offenses and the interpretation of particular treaty provisions, the growth of an international treaty law of extradition has provided hopeful evidence of the capacity of states to cooperate effectively where there is a substantial common interest and where the need for cooperation is sufficiently appreciated..$^{104}$

If international law has fared somewhat better with respect to property and control, it may be said to have fared still better with respect to problems of jurisdiction. Presumably this should be attributed to the circumstance that the subject embraces many sources of irritation but few of the great prizes for which nations fight. An increasing multiplicity of contacts in the less explosive areas of inter-

${ }^{102}$ Since the above was written the United States Government has taken notable steps in the direction of conservation. See Proclamation 2667 and Executive Order 9633, concerning the subsoil of the continental shelf, and Proclamation 2668 and Executive Order 9634, concerning the conservation of contiguous fisheries, (1945) 10 FEDERAT REGISTER 12303-12305.

${ }^{103}$ I, 798-809. Cf. Research in International Law, Jurisdiction with Respect to Crime (1935) 29 ANs. Jour. INT. L. SUPP. 435-651. $15-434$.

104 II, 1012-1063. Cf. Research in International Law, Extradition (1935) 29 ibid., 
national relations has encouraged a progressive development of principles and procedures of adjustment. Here more than elsewhere customs of general acceptance and practical utility have slowly emerged. Here national legislation has frequently followed a pattern suggested by international custom and here it has been notably possible for national courts to make distinctive contribution through their decisions in cases of international import. An extensive supplementing of custom through rule-making treaties has been particularly notable.

Unfortunately the areas of unsettlement and tardiness of agreement are no less notable. Earlier differences among national political systems have given way to new divergences of social and economic purpose and the state in commerce has presented new problems which are not easily resolved through application of the old principles and procedures. The adjustment of conflicts of jurisdiction upon the sea, notwithstanding their increasing importance, has been advanced but little. Conservation and development of the resources of the sea have been seriously impeded or frustrated by negation. Conflicts of penal jurisdiction have been exaggerated, in part naturally because of basic differences in culture and administration, and in part needlessly in reliance upon unwarranted generalization from superficial analyses of practice. Within the ambit of the general subject there are bases upon which to build, but there is much building to be done before order and justice can have even modest assurance.

Before leaving this subject it should be said that the exercise by one state of so-called extraterritorial jurisdiction within the domain of another, where the latter is indisposed or unable to perform required duties of jurisdiction, has had an interesting history and is probably a vanishing phenomenon. It is enough to note that the treatise writer gives it some attention. ${ }^{105}$ The general duties of jurisdiction, particularly in relation to foreign persons or property, ${ }^{106}$ may be considered convemently under the heading of nationals and their protection.

\section{NATIONALS AND THEIR PROTECTION}

Nationals are persons who owe allegiance to the state by virtue of a more or less permanent relationship which the state determines. They are individuals who have become members, by one criterion or 
another, of the state community. It is said that the power of the state to confer such membership is not unlimited; and it is probably true that nationality may not ordinarily be imposed in invitum. Actually, however, the area within which the state is free to act is wide indeed; and the determination of problems of nationality requires reference to widely variant national laws. ${ }^{107}$ It is noteworthy that Hyde devotes the major part of an extensive treatment to the laws and practices of the United States. ${ }^{108}$

Nationality is conferred at birth or by naturalization. Nationality at birth is conferred jure soli, by right of the place, or jure sanguinis, by right of blood, or by some combination of the two. From an examination of the nationality laws of seventy states, our best informed American expert on the subject concludes that "seventeen are based solely on jus sanguinis, two equally upon jus soli and jus sanguinis, twenty-five principally upon jus sanguinis but partly upon jus soli, and twenty-six primcipally upon jus soli and partly upon jus sanguinis." 109 It thus appears that some combination of the two principles is found in the laws of most countries, that international law excludes neither and prefers neither, and that multiple nationality at birth is by no means an unlikely phenomenon.

Nationality by naturalization is collective, where territory is transferred together with the allegiance of its inhabitants, or individual, where there is compliance with the conditions and procedures which national laws may prescribe for admission to membership in the state community. Individual naturalization, in turn, may be formal, as where the individual renounces allegiance to one state and swears allegiance to another after compliance with the conditions imposed, or informal, as where a wife becomes naturalized by virtue of the naturalization of the husband or a minor by virtue of the naturalization of the parent. Whether and to what extent naturalization in one state operates to expatriate in another are "burning questions," long extremely troublesome and still largely unresolved. Conflicts of view stem largely from the conflicting interests of states of emigration and states of immigration. There has been effort, none too successful, to alleviate such conflicts through bipartite conventional ar-

107 II, 1064-1068. Cf. Research in International Law, Nationality (1929) 23 AMr. Jour. INT. L. Supr. 11-129; FlourNoX and Hudson, Natjonality Laws (1929). $108 \mathrm{II}, 1068$-1187.

109 Flournoy, in Research in International Law, Nationality (1929) 23 Asr. Jour. INT. L. SUPP. 29. 
rangements. At the Hague Conference for the Codification of International Law of 1930, an effort to find general bases of agreement "fell among thorns" and little of substance was accomplished. ${ }^{110}$

There are apparently no limitations upon the power of the state to denationalize its own subjects. Conflicts of national laws may result in individual denationalization; and denationalizations en masse, on political or racial grounds, were a recurring phenomenon of considerable importance in the period between world wars. Indeed the situation of the stateless person was rapidly becoming a problem of major international concern. ${ }^{111}$

As a correlative of his allegiance, the national is generally considered entitled, under his national law, to the protection of the state to which he belongs. The decision to protect and the nature and scope of interposition in the national's behalf are within the discretion of the state concerned, ${ }^{112}$ but states do in practice assert an extensive authority to protect the interests of their nationals wherever they may be. They insist upon respect for asserted minimum standards in the treatment of their nationals found temporarily or permanently within the authority of other states. The efficacy of their insistence is in rather obvious proportion to their relative influence or power.

From the multiplicity of international contacts resulting from diplomatic interposition in behalf of nationals, and from an increasing tendency during the past century to adjust such claims through arbitration, there has developed a most interesting and significant phase of modern international law. A great many ad hoc commissions or tribunals have been created and thousands of awards or decisions have been handed down. Experience with an adjustment process having many of the characteristics of judicial settlement has thus been cumulative. From this experience useful principles and procedures have emerged. ${ }^{113}$

110 II, 1143-1159. Cf. Flournoy, Nationality Convention, Protocols and Recommendations Adopted by the First Conference on the Codification of International Law (1930) 24 Asr. Jour. INT. I. 467-485.

111 Cf. 1 OpRENHens, op. cit. supra note 4, 533-536.

112 II, 890.

113 II, 8\$2-1012. Cf. Research in International Law, Responsibility of States (1929) 23 Aar. Jour. Int. L. Supp. 131-239; Borchard, Diplonfatic Protection of Citizens abroad (1915); DunN, The Protection of Nattonals (1932); Ralston, Law and Procedure of International Tribunats (1926); Whiteman, Damagees IN InternaTIONAL LAW (1937-1943). 
It is thus established as a general rule that in the absence of special agreement the claimant in whose behalf a state interposes must lave been a national at the time the claim arose and a national continuously thereafter, at least up to the time when the claim was formally presented. Practice indicates, moreover, that a claim will not be countenanced if the claimant is also a national of the respondent state. ${ }^{114}$ Subject to various exceptions, which are none too clearly defined, the claimant is generally required to liave been reasonably diligent in the exhaustion of local remedies before his claim may properly become the subject of diplomatic interposition. ${ }^{115}$ Damages may be recovered in the claimant's behalf for wrongful injuries attributable directly to abuse of authority or position on the part of officials or agents of the respondent state. In varying circumstances the decisions recognize minimum standards of administration wlich may be ignored only at the risk of international responsibility. ${ }^{110}$ Damages may also be recovered in the claimant's behalf for wrongful injuries attributable initially to the acts of private individuals where there is delinquency in prevention or negligence in prosecution. The principle lias been found applicable in a wide variety of circumstances and notably in cases of injury to the nationals of other states through mob violence. ${ }^{11 \tau} \mathrm{A}$ more or less comparable principle has found occasional application in cases of injury to the nationals of other states by unsuccessful insurgents. The latter problem is more complicated, however, and there is divergence of view and considerable confusion of thought. ${ }^{118}$ Damages for breach of contract between the national claimant and the government of another state are in a somewliat different category. The mere breacli of such a contract is not regarded as an international wrong. The instances are numerous, however, in which breach associated with other delinquencies lias been found to justify interposition. While practice has not been uniform, claims conventions have frequently embraced claims of contractual origin. The so-called Calvo Clause in such contracts, formulated in terms intended to exclude diplomatic interposition, has been the subject of long standing controversy still unsettled. In the absence of rules or primciples for the relief of insolvent debtor states, claims on defaulted

114 III, 893-908.

115 II, 909-922.

116 II, 924-936.

117 II, 937-952. 
public bonds are generally the subjects of diplomatic rather than legal adjustment. The Hague Convention of 1907 limiting recourse to armed force for the recovery of contract debts had only limited acceptance among states thought to be its principal beneficiaries. ${ }^{119}$ Efforts to find bases of clarification and agreement on the broader subject at the Hague Codification Conference of 1930 were unsuccessful. ${ }^{120}$

International law with respect to the topics thus briefly reviewed is indeed a curious mixture of conflict and erratic progress. The law of nationality within each state is considered a domestic matter to be determined according to assumed political, military, social or economic needs. The bases of a fragmentary international practice are permissive rather than harmonizing. The reconciliation of conflicts has been negligible.

Turning to the protection of nationals, we are confronted with what is in all respects international law's most impressive and significant experience with arbitral or quasi-judicial settlement. However, the experience is impressive by contrast only and significant chiefly for the unexplored possibilities of justice under law which it so patently suggests. The necessary tribunals are rarely available as claims arise but are constituted ad hoc at infrequent intervals and only as claims accumulate in sufficient numbers to compel the attention of departments of foreign affairs. Their jurisdiction is determined by expediency and their procedures by an emerging but somewhat chaotic practice. So far as individual claimants are concerned, the awards are rarely timely or efficacious but, like the sins of the fathers, are likely to be visited upon the children even unto the third and the fourth generation. Too often their bounty is beneficial only to remote kin and to claims attorneys who specialize in such business.

If agreement were attained on basic principles, it would appear not only feasible but imperative that symbolic international adjudication be supplemented by a system of local or itinerant judges capable of settling claims in behalf of nationals as they arise. To date, however, the obstacles to such agreement have proved insuperable. On the one hand, states able to accommodate immigration, of relatively

118 II, 979-988.

$119 \pi$, 988-1009.

${ }^{120}$ Cf. Borchard, "Responsibility of States" at the Hague Codification Conference (1930) 24 ANr. Jour. INT. L. 517-540. 
immature economic development, or in need of foreign capital and enterprise, have frequently been somewhat less effective than others in the protection of aliens and correspondingly reluctant to concede responsibility for injuries to the nationals of other states. On the other hand, states having population, capital or enterprise for export have frequently been somewhat more effective and in any case correspondingly insistent upon high standards of protection for their nationals abroad. There are exceptions, of course, but the gap is notable and has never been satisfactorily bridged.

\section{INTERCOURSE AND AGREEMENTS}

The frustration of efforts to bridge this or other gaps through international agreement has not been due to any deficiencies of practice with respect to intercourse and agreements. Few topics among the customs and practices of nations have a more ancient lineage or a more embracing development. International law stems, in truth, from the interrelationships of the earliest political groups of the human race. From earliest historic times the groups of man have been in varying degree concerned about the amenities of their intergroup communications and understandings. In our time, and among members of the modern state community, these amenities have become the subject of a formal and relatively comprehensive practice.

At the diplomatic or political level, practices with respect to intercourse are grounded largely upon custom and embrace inter alia the methods and procedures of intergovernmental communication and negotiation, the classification, rank and precedence of diplomatic representatives, the beginning and end of diplomatic mission, the rights and duties of diplomats, including their jurisdictional immunities, the formalities and techniques of diplomatic negotiation, and various matters of ceremonial. ${ }^{121}$ At the commercial or economic level, they are defined largely in treaties and embrace the classes of consular officers, their designation and reception, and the varied privileges and immunities which have been found necessary to the discharge of their functions under modern conditions of international life. ${ }^{122}$

"Agreements between States are a necessary incident of interna-

121 II, 1211-1310. Cf. 1 OPPENHEDs, op. cit. supra note 4, 596-641; SATow, Guide to Diplomeattc Practice (3rd. ed. 1932).

122 II, 1311-1367. Cf. 1 OPPENHETM, op. cit. supra note 4, 644660. 
tional intercourse, and increase in number and variety as that intercourse expands and produces a consciousness of inutual dependency." 123 Measured by the many thousands of treaties and less formal agreements which have been concluded in modern times, it would appear that "consciousness of mutual dependency" has grown apace. At the same time there has developed a body of practice with respect to international agreements, extensively rationalized by recourse to private law analogies, ${ }^{124}$ concerning capacity, validity, mutual assent, formalities of negotiation and conclusion, operation and enforcement, interpretation and termination. ${ }^{\mathbf{1 2 5}}$

Except in the case of dependent states, capacity to enter into agreements with other states is assumed to be virtually unlimited. In theory there may be restrictions upon validity, but in practice such restrictions are well-nigh nonexistent. There are no required forms, though agreements falling into conventional categories of greater dignity or permanence are usually expressed in formal treaties or conventions, bipartite or multipartite, while undertakings of more restricted or less enduring import may find expression in modi vivendi, protocols, executive agreements and the like. A requirement of registration was first formulated in Article 18 of the League of Nations Covenant, which stipulated that "every treaty or international engagement entered into hereafter by any Member of the League shall be forthwith registered with the Secretariat" and that "no such treaty or international engagement shall be binding until so registered." 126 Mutual assent must be appropriately and sufficiently manifested, but here there is striking departure from the most elemental principles of private law. Assent given under duress, if formally sufficient, is as binding as assent given freely. In the negotiation and conclusion of the more formal agreements, there is commonly observed an impres-

123 II, 1369.

124 Cf. LaUterpacht, Private Law Sources and ANalogies of International LaW (1927) 155-202 and passim.

125 II, 1369-1558. Cf. Research in International Law, Treaties (1935) 29 Am. Jour.

INT. L. SUPP. 653-1226; 1 OPPENEEIMr, op. cit. supra note 4, 683-757.

120 Cf. UnIted Nations Charter, art. 102, which reads as follows:

"1. Every treaty and every international agreement entered into by any Member of the United Nations after the present Charter comes into force shall as soon as possible be registered with the Secretariat and published by it.

"2. No party to any such treaty or international agreement which has not been registered in accordance with the provisions of paragraph 1 of this Article may invoke that treaty or agreement before any organ of the United Nations." 
sive and important body of ritual concerned with the authority to negotiate and sign, the formalities of langnage, description of parties, alternat, protocols of meetings and signature, and the procedures of ratification, exchange and deposit of ratifications, reservation and adherence. $^{127}$

Treaties are binding, of course, only upon the parties thereto. ${ }^{128}$ They may or may not require national implementing legislation, depending upon their terms and the requirements of national law. In the United States their immediate efficacy is fortified by the provision of the national Constitution that "all Treaties made, or which shall be made, under the Authority of the United States, shall be the supreme Law of the Land; and the Judges in every State shall be bound thereby, any Thing in the Constitution or Laws of any State to the Contrary notwithstanding." 120 Pacta sunt servanda is thus translated from the formulae of international jurisprudence into a working precept of national law. ${ }^{130} \mathrm{It}$ has been the present writer's observation, contrary to prevalent lay notions, that, if engagements undertaken under duress are excluded, international agreements will be found to have been more consistently observed than contracts in private law.

The interpretation of treaties has been the subject of extensive consideration in both national and international judicial decisions. As in the interpretation of private contracts, the problem is essentially one of ascertaining the sense in which the parties have employed the terms of their choice. Restrictive rules of evidence, so troublesome in the common law, have been largely avoided. Real conflicts between plain meaning and the import of extrinsic evidence have been relatively infrequent. The Permanent Court of International Justice has made some of its most useful contributions to international law in this field and appears to have been progressively inclined toward discovery of the essential sense of the agreement through realistic resort to all relevant sources of interpretation. The so-called rule of liberal construction, so often affirmed in opinions of the United

127 II, 1374-1450. Cf. SATOW, op. cit. supra note 121.

${ }^{128}$ Cf. UnITED Nations CEARTER, supra note 1, art. 103, which reads as follows:

"In the event of a conflict between the obligations of the Members of the United Nations under the present Charter and their obligations under any other international agreement, their obligations under the present Charter shall prevail."

129 U. S. Const., ART. VI, §2.

130 II, 1451-1467. 
States Supreme Court, would appear to be chiefly significant as an indication of similar approach. The artificial canons of construction which are to be found in some of the treatises on international law have proved of doubtful utility and have been relatively little used. ${ }^{131}$

The termination of treaties is a subject which has been much mooted over the years and which embraces some major unsettled problems. Naturally termination pursuant to the express terms of the agreement gives rise to few difficulties. The same may be said of the termination of bipartite agreements by subsequent agreement between the parties. There is more of difficulty, for obvious reasons, in the termination of multipartite agreements by subsequent agreement between the parties. Termination upon the initiative of a single party, without subsequent inter-party agreement, is sometimes sought to be justified by reference to changed conditions beyond the contemplation of the parties when the original agreement was concluded. "It is not easy to determine," says Hyde, "what changes in conditions confronting the parties to a treaty serve to permit either of them to free itself from the burdens of the compact."'132 Hyde's comment would appear to be safely on the side of understatement. In the absence of reasonably well organized international cooperation, the difficulties have been well-nigh insuperable. The so-called doctrine of rebus sic stantibus has been invoked in varied circumstances and the subject has been confused by a good deal of doctrinaire evasion. Until cooperation has been inore effectively implemented, however, and so long as agreements are improvidently made without adequate provision for termination and are rendered inapplicable by changing conditions or are imposed by force upon states later permitted to recover power, the problem will surely bedevil the good understanding of nations. A change in the form of government of a contracting state does not terminate its treaties. It is generally otherwise where the identity of the state itself is wholly lost, but the question of succession to treaty obligations upon succession of states or cessions of territory is a subject of neither clearness of thought nor uniformity of action. Denunciation by one state because of alleged violations on the part of another is almost as troublesome as termination because of changed conditions and fundamentally for similar reasons. The effect of war

131 II, 1468-1502.

132 II, 1523. Cf. 1 Oppentenr, op. cit. supra note 4, 738-745; and Brierly, The Shortcomings of International Law, op. cit. supra note 34, 15-16. 
upon treaties, whether to abrogate, suspend or bring into operation, has been extensively considered in theory and practice and in more recent times has frequently been the subject of appropriate arrangements in the treaty of peace. ${ }^{133}$

In summary it is perhaps superfluous to observe that few subjects expose the paradoxes of international law more sharply than the law of intercourse and agreements. There is great age and shocking artlessness. There is much that serves the ends of an ordered justice and much of excessive formalism. As under other legal systems, social adjustment is accomplished largely through continuing discussion and negotiation conducted with substantial respect for accepted standards, but under no other system is there so much concern for the procedures of proceeding or so signiflcant a reliance upon the vade mecum of negotiating practice. There is maturity, as in the interpretation of treaties, and retarded development, as in succession to treaty obligations or terminations for breach. There are strong bases of order, as in treaty observance, and recurring invitations to chaos, as in the reconsideration of inapplicable treaties and in treaties made under duress. Nowhere except in the adjustment of differences and in war, topics presently to be considered, does emergence from the primitive ${ }^{134}$ await more obviously upon improved organization of the processes of international cooperation.

\section{ADJUSTMENT OF DIFFERENCES}

The procedures of adjustment are at once the hope and the despair of all who reflect seriously upon the relations of nations. The treatise writer reminds us that there are amicable modes of adjustment and non-amicable modes short of war. Amicable modes include negotiation, good offices and mediation, commissions of inquiry, commissions of conciliation, arbitration and adjudication, and the more comprehensive organization of adjustment procedures attempted in the Covenant of the League of Nations. ${ }^{135}$ Non-amicable modes are variously described as the withdrawal of diplomatic relations, retorsion, retaliation, reprisals, pacific blockade, embargo and non-intercourse. ${ }^{136}$ Except for negotiation, the former have had no more than

133 II, 1516-1558.

134 Cf. BRIERLY, op. cit. supra note 4, 38-39.

135 II, 1559-1653. Cf. 2 OPPENHEIM, of. cit: supra note 4, 3-96.

136 II, 1654-1678. Cf. 2 OPpENHEIr, o1. cit. supra note 4, 106-162. 
a fragmentary and rudimentary development. The latter are manifestly mere variations on self-help and too often likely to prove no more than a prelude to war.

As already noted, most adjustments of differences among nations are the result of a continuing process of discussion and negotiation. This is of course normal under any legal system. Somewhat like the counsellor ấ law, it is the continuing business of the foreign service official to prevent misunderstanding, allay irritation and find bases of compromise and agreement. The abnormality of the international system becomes apparen $\iota$ when we come to consider the alternative procedures to which recourse may be had when negotiation fails. We may consider these procedures in the order in which Hyde presents them.

The procedures of good offices and mediation have been formalized in multipartite treaties, but actually have been used with relative infrequency. Commissions of inquiry and commissions of conciliation are contemplated in a great number of treaties, bipartite or multipartite, but on the whole their use has been negligible. The development in practice of international arbitration has been vastly more impressive, though it must be conceded that it shines by contrast rather than because of its proven virtues.

Arbitration procedure has been outlined in a great number of bipartite treaties and in treaties of general rule-making effect and has been extensively and successfully used. In the accumulated awards there is discernible an emerging body of rudimentary principle with respect to the necessary procedural techniques, the competence of tribunals, res judicata and the finality of awards, awards in excess of the submission, unconscionable awards, interpretation of international instruments, damages and kindred matters which may some day contribute substance and efficacy to the law of nations. ${ }^{137}$ It is to be emphasized, however, that the emerging principles are still extremely rudimentary. The so-called Permanent Court of International Arbitration, organized pursuant to the Hague Conventions of 1899 and 1907 for the Pacific Settlement of International Disputes, has actually been no more than a small administrative office, a panel of avail-

13T II, 1626-1642. Cf. Hudson, Internationad Tribunals (1944); Ralston, LaW and Procedure of International Trubunats (1926); Sandifer, Evidence Before International Trubunats (1939); Whitearan, Dadiages in International LaW (1937-1943). 
able arbitrators and an outline of agreed procedures. Throughout its years it has been used in approximately a score of cases of which only a few may be said to have been of first-rate importance or to have contributed substantially to the progress of the law. ${ }^{138}$ The United States has had recourse to arbitration throughout its history in a wide variety of disputes concerning boundaries, treaty interpretation, pecuniary claims, war claims and other matters of alleged international right or duty, but in the past has been characteristically reluctant to pledge arbitration of future differences except within the narrowest of limits. ${ }^{139}$

Adjudication in the mternational sphere is not unlike arbitration in its essential features. Both envisage adjustment in accordance with the law and practice of nations. Unlike the more casual processes of arbitration, however, adjudication is assumed to require permanent tribunals and to assure a larger measure of jurisdictional and procedural consistency. It should also assure a somewhat more favorable climate for the progress of the law from precedent to precedent. It has had a brief but hopeful history since the Permanent Court of International Justice was opened at The Hague in 1922 as a constituent part of the plan of organized cooperation envisaged in the Covenant of the League of Nations. The Court's life was too brief to give reliable indication of its ultimate siguificance. In constitution, organization and procedure it was a truly judicial body. Time and circumstance considered, it had a fair amount of judicial business. While its remoteness from the unsettlements of a disordered world and its relative inaccessibility rendered it chiefly of symbolic importance, in the period in which it served, its contributions to law, particularly in the field of procedure and the interpretation of international instruments, were an augury of useful service. ${ }^{140}$

The hopes, accomplishments and failures of the more embracing program of the League of Nations have been of such recent history

138 II, 1605-1612. Cf. ScotT, The Hague Court Reports (1916); The Haque Court Rezorts, Second Series (1932).

139 II, 1586-1605. Cf. BRIERLY, op. cit. supra note 4, 33-45. And cf. UNITED Natrons Charter, supra note 1, c. 6 and passim.

140 II, 1614-1626. Cf. Hudson, The Permanent Court of International Justice, 1920-42 (1943) ; Hudson, Wordd Court Reports (1934-1943); and the series of articleg by the same author on the work of the Court appearing annually in the January number of the American Journal of International Iaw from (1923) 17 AMr. Jgur. INT. L. 15. 
as to require neither descriptive summary nor critical comment. ${ }^{141}$ In proportion to the things to be done, it is apparent enough that the accomplishments were relatively meager. The causes of failure will no doubt be the subject of endless debate, and with that we may leave them. It is patent that they are of present importance chiefly as way signs of policy for cooperation reorganized under the United Nations Charter.

"On occasions," says Hyde, "when their differences with others have not been adjusted by amicable means, aggrieved States not infrequently have recourse to non-amicable measures for the purpose of obtaining desired redress or of removing the cause of controversy. Such measures may or may not lead to war." ${ }^{142}$ There is a broad and undefined area within which such measures are permissible. Thus the severance of diplomatic relations is never internationally illegal. Retorsion, defined as action taken to compensate for damage suffered or to deter objectionable action, may be in answer to allegedly illegal conduct or to conduct which is merely unfriendly and may assume a variety of forms. Reprisals are described as the taking or withholding of any form of property of a foreign state or its nationals as a means of obtaining reparation for allegedly illegal conduct for which redress has been refused. They are "essentially the remedy of the strong against the weak." ${ }^{1143}$ Pacific blockade is a blockade having impact presumably only upon the parties immediately concerned, though maritime powers have never been able to agree upon its scope. Embargo may take various forms and may be pacific or hostile. Nonintercourse is the permissible recourse of a state which would save itself or its nationals from the allegedly illegal or reprehensible conduct of another.

Thus hope and despair have marched abreast where hope modestly realized may some day point the way to an approaching maturity. There has been of course no such approach to maturity in our time. The long struggle for a minimum of order and decency in the adjustment of international differences is yet to be won. Of the socalled amicable modes, only negotiation has come of age. And negotiation, when unsupported by informed opinion and the will to un-

141 Cf. BRIERLY, op. cit. supra note 4, 61-72; 1 OPPENEELM, op. cit. supra note 4, 299-346; 2 OPPENHEDT, op. cit. supra note 4, 84-96, 125-143.

142 II, 1654.

143 II, 1666. 
derstanding, is repeatedly frustrated. More pretentious procedures have inultiplied on paper but have been little used. There have been glinpses of a firmer order, in posse, in the long experience with arbitration and the briefer history of judicial settlement; but always they have been caught unsteadily across the desolate no-man's land of self-help, a land strewn with the wreckage of nonamicable adjustment and periodically desolated by war. This is only another way of saying that in its procedural aspects the law of nations has been a jungle law slightly ameliorated by fragmentary and hesitant progress in the direction of juridical order.

IX. WAR

Hyde's third and last volume, embracing nearly one-third of his entire treatise, is devoted to war. Nor is the treatment disproportionate for one who would "see things as they are." The treatise writer is concerned primarily with the fact and its legal incidents rather than with causes and cures.

"It may be doubted," says Hyde, "whether as yet the family of nations has undertaken to impose upon any of its members a legal duty not to wage war for the purpose of exacting redress for wrongs sustained when reparation is obtainable through other processes."114 As of the time of writing, Hyde was safely on the side of understateinent. For the realist the path was unmistakably indicated. Indeed, so long as it lies within the power of states to seek redress or advantage through recourse to war the publicist must be prepared to understand and expound a host of legal incidents and consequences. In some of its aspects the subject probably has a longer history than any other part of the law of nations. In any case there is a vast accuinulation of practice, national and international, which illuminates in varying degree the tortuous course of hostile relationships.

Thus there is law for the lawyer, as well as for the diplomat and the soldier, im practices with respect to the beginning and the termination of war. ${ }^{145}$ Stemming from the relations between belligerents, there is lawyer's law in the impact of war upon communications, contracts, judicial remedies, enemy persons, enemy property and commerce. ${ }^{146}$ So too, as between belligerents and neutrals, with respect to

144 III, 1698.

145 III, 1693-1698, 2385-2418.

146 III, 1699-1743. 
neutral persons and property within belligerent territory. ${ }^{14 r}$ As between belligerents, there is law for the fighting man in the practices and procedures which prevail between enemies with respect to military and naval communication and agreement $t^{148}$ and with respect to the qualifications of belligerent forces, belligerent neasures and instrunientahities, and the treatment of prisoners and the sick and wounded. ${ }^{149}$ In land warfare there has developed an extensive and important body of practice and doctrine concerning the incidents of military occupation. ${ }^{150}$ In naval warfare distinctive practices concerning visit and search, capture, enemy character in relation to property at sea and the like are of immediate import for the naval officer and frequently of ultimate import for the lawyer who appears in proceedings for the condemnation of prize. ${ }^{151}$ In its impact upon the commerce of neutrals, naval warfare has also developed an extensive body of prize law affecting the carriage of contraband ${ }^{152}$ and the running of blockade, ${ }^{153}$ an odd jurisprudence of paradoxes under which the neutral trader has the right to risk if he chooses and the belligerent the right to seize and confiscate if he can. The entire law of neutrality is poised precariously upon the verge of a similar paradox in its effort to keep in balance the belligerent's interest in exploiting neutral aid and the neutral's duties of abstention or prevention. Enlistments and recruitment, loans and contributions, the munitions traffic and trade in ships or aircraft, asylum and internment, the use of radio facilities and bases of operations in neutral territory are among the more familiar topics in a larger practice struggling to achieve and hold some measure of general recognition. ${ }^{154}$

It is unnecessary for present purposes to attempt more detailed inventory of the laws and practices of nations which fall under this general heading. Patently we are here confronted with a body of practice which is an incident or by-product of the negation of law. Right struggling even feebly against might in such a milieu is a miscast figure of speech. Patently we are dealing with practice which

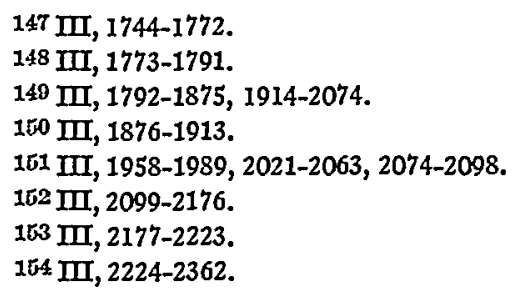


can achieve no more than a little order where the hard core of common interest makes a minimum of order imperative, a little amelioration where unmitigated brutality may serve no substantial military purpose, a little tolerance where intolerance invites senseless retaliation, or a little adjustunent where unadjustment may open the floodgates to complete chaos. This is not to say that the subject matter is unimportant. It is important and will remain important so long as war and the threat of war continue to bedevil the security of mankind. It is merely to say that there can be a kind of law among nations in this area in a restricted and special sense only. International law brewed in the witches caldron of warfare may be something of an antidote. Certainly it is no prescription for decency or justice. ${ }^{165}$

\section{$\mathrm{X}$. SOME CONCLUSIONS}

This concludes our attempt at inventory. Needless to say, it is not anticipated that anyone will agree with all of it. There will be those no doubt who think some parts of the whole too lightly valued. Others presumably would depreciate at times with a firmer hand. The attempt has been somewhat like that of the venerable divine who took "The Inspiration of the Holy Writ" as his topic and announced that he would "review the scriptures from Genesis to Revelations with special emphasis upon the Acts of the Apostles." Divergences of appraisal are unavoidable among those who may venture upon so ambitious an undertaking. The divergences are unimportant, however, so long as the over-all appraisement is substantially correct. Enough has been reported, it is believed, to warrant certain general and perhaps rather obvious conclusions.

In the first place, the community of international law is the community of the world's peoples. It is a community of great peoples and small peoples, of peoples mature in the arts and skills of government and law and others hardly on the threshold of essential experience, of peoples clinging tenaciously to vast empires and others of small

155 "To hold at one and the same time that states are legally bound to respect each other's independence and other rights, and yet are free to attack each other at will, is a logical impossibility. Yet that is what the accepted international legal theory to-day requires us to do, and it leaves us therefore with no real answer to attacks on the reallty of international law such as are made by Treitschke and many others, especially German, writers." BRIERLX, op. cit. supra note 4, 21. Cf. ibid., 19-32; and an anonymous article entitled The League of Nations and the Laws of War (1920-21) B. Y. B. INT. L. 109-124. (1921) 19 MICH. L. REv. 835-848. 
domain, of peoples rich in basic resources and others who are relatively poor, of peoples who are landlocked and others who look to the sea, of peoples conscious of an awesome military might and others without it, of peoples who live in relative security and others who live in fear, and of peoples of the most varied languages, cultures, faiths and political ideologies. In brief, the community of law is a euphemism for a vast and complicated confusion. For those who seek to rationalize it juridically there is bound to be the strongest temptation to ignore physical facts and cultivate metaphysical nonsense.

In the second place, the community of international law has been an unorganized community. There has been in the past no general recognition of obligation to participate in its conferences or to accept the results of conference deliberations. Until quite recent times equality of voting and the requirement of unanimity have been considered basic principles of conference procedure. The term international government, based hopefully upon a fitful progress in administrative, technical or routine matters and popularized during the League of Nations interval, has been largely a misnomer. Such law as has emerged has rested both theoretically and practically upon a wellnigh universal consent or acquiescence. This is to say, of course, that the law has made substantial progress where there was no substantial controversy and that the prime function of law as a process of anticipation and adjustment in the light of past experience and its conscious amelioration has been largely lacking.

In the third place, the unorganized community of nations has succeeded in developing only the most primitive means of conscious and continuous law making. The international conference as an agency of so-called international legislation has had persuasive apologists. International instruments of rule-making effect have appeared increasingly in the records of international life during the past threequarters of a century and particularly during the League of Nations interval. Attention has been called to such instruments from time to time throughout the present inventory. By gathering together everything remotely in point, of concern to three states or more, local or general and ratified or not, it is possible to create the impression of an impressive achievement; but the impression is largely illusory. Such things are not to be weighed by the pound or even by the page. It is somewhat like the imaginative business of laying end to end to see how many times something will encompass the earth. It is even 
more illusory to describe the accumulated bulk as "the legislative content of international law."156 Actually there has been a hopeful progress in the making and implementing of rule-making treaties, bipartite and multipartite, but the international community has yet to mount the threshold of anything fairly described as an international legislative process. ${ }^{157}$

In the fourth place, the unorganized community of nations has succeeded in developing only the most rudimentary of procedures for the adjustment or settlement of disputes. The primitive condition of international adjustment practice is strongly intimated in the formalism of its negotiation procedures. It is further indicated in the multiplication of agreements with respect to patently elementary devices which are rarely if ever used. It stands revealed in the chaotic history of international arbitration and in the confined and symbolic import, during modern civilization's two most critical decades, of the processes of international adjudication. It is writ large throughout the history of international law in unrestrained rights of recourse to the device of self-help. There is a place to build and some of the stuff of which to raise a more useful structure, but it may hardly be contended that adjustment according to law has yet emerged as more' than a hope imperfectly supported by the records of troubled experience.

In the fifth place, as is inevitable in a community which has yet to achieve a minimum assurance of order, international law is a law of strongly asserted rights ineffectively balanced by correlative obligations. The lack of balance is exemplified in pervasive insistence upon each state's right to choose its own form of government, define the allegiance of its own people, do what it will with its own nationals, exclude or discriminate against the nationals of others, determine the scope of intercourse with others, act in self-defense and generally remain free from all external control. It is manifested in the assertion of exclusive and generally irresponsible rights of territorial authority or jurisdiction and above all in the ever present right to frustrate agreement and appeal to the ordeal of battle. There are emergent obligations, particularly in the less controverted areas of international relationships, but more often than otherwise they are patently

1566 Hudson, Internationat Legistation (1937) vii; International Tribunats (1944) 109.

157 I, 139-143. 
imperfect, feebly delineated, and without assurance of a widespread acceptance and support.

In the sixth place, it must be said in all candor that international law has been in extraordinary degree a law in literature and, moreover, a law in the literature of vast aspiration. The influence of theologians upon its literary genesis is familiar history. Said Grotius: "Throughout the Christian world I observed a lack of restraint in relation to war, such as even barbarous races would be ashamed of; I observed that men rush to arms for slight causes, or no cause at all, and that when arms have once been taken up there is no longer any respect for law, divine or human; it is as if, in accordance with a general decree, frenzy had openly been let loose for the committing of all crimes. ${ }^{3158}$ Accordingly Grotius resolved to write a book in which discriminating recourse would be had to "the testimony of philosophers, historians, poets, finally also of orators." "159 Yet Grotius, by contrast with many of those who were to follow in his steps, was a good deal of a realist. "On no subject of human interest, except theology," said the late John Chipman Gray, "has there been so much loose writing and nebulous speculation as on International Law." 160 The way is devious and difficult indeed for one who would seek bases or forecasts of adjustment in this labyrinth of pseudo-juridical effusion.

International law, as previously suggested, is a jurisprudence of extraordinary paradoxes. It is a system of global vistas and sterile foregrounds, of vast pretensions and restricted performance, of great age and impressive immaturity, of tempting analogies and factual frustration, of quest for right under the inescapable shadow of recourse to might and of groping for order where disorder is more easily precipitated than restrained. Imperfect as these observations may be, they should nevertheless illuminate a little the goals accepted tentatively at Dumbarton Oaks and more fully delineated in the Charter of San Francisco.

The Charter of San Francisco is no blueprint of perfection for an imperfect world. It is a relatively realistic attempt to so organize the processes of international cooperation that, given the will to implement it, an essential minimum of peace and order may be assured in this generation. If the essential mimimum of peace and order can be

158 De Jure Belli ac Pacis (1625) proleg. 28.

159 Ibid., proleg. 40.

100 Gray, Nature and Sources of the LaW (1909) \$279. 
maintained in this generation, however precarious our hold upon it may seem from time to time, there should be soil and climate in which somewhat sturdier plants may take root and grow. In proportion as it proves possible to "establish conditions under which justice and respect for the obligations arising from treaties and other sources of international law can be maintained," it should be possible to encourage and foster "the progressive development of international law" and other forms of international cooperation. ${ }^{101}$

Patently there must be a significant sequence of accomplishments in the realization of the Charter's objectives. There should be neither uncertainty as to immediate objectives nor confusion through diffusion of effort. There can hardly be overemphasis upon the elemental principle of first things first. It is not immediately necessary to perfect a comprehensive legislative process, to invest the International Court of Justice with an embracing and obligatory jurisdiction, or to greatly multiply the specialized agencies of international cooperation. There will ultimately be a time and occasion, if the initial enterprise succeeds, for considering these things on their merits.

The initial challenge may be stated in a single, elemental and in'escapable question: Can the nations unite their strength, as they have resolved in the Charter's preamble, "to maintain international peace and security, and to ensure, by the acceptance of principles and the institution of methods, that armed force shall not be used, save in the common interest?" It is only in successful response to this elemental challenge thiat the atomic age in which we now live may ultimately become an era of order and progress rather than an era of mutual destruction.

161 Cf. BRIERLY, op. cit. supra note 4, 73-94. 